\title{
Production and Technology of Iron and Steel in Japan during 1982*
}

\section{By Tsuneyo IKI**}

\section{Economic Situation Surrounding Iron ana Steel Industry}

Although there has been a slight improvement in domestic demands, the export continued to fall since late 1981. As a whole the Japanese economy remains stagnant with little sign of recovery, still necessitating inventory adjustment.

Taking a close look on it from final demand aspect, consumers' spending is picking up a little owing to low inflation rate of 2 to $3 \%$. But in the private industrial sector, large companies are moving toward reduction of equipment investment reflecting deteriorating circumstances for investment and medium and small firms are not showing much enthusiasm in investment. Private housing construction continues to be at a low level. In the field of public construction, a market stimulant measure of forward awarding of contracts was adopted in the beginning of 1982, but this field did not show sign of recovery, reflecting many restrictive factors, notably a sizable government revenue deficit.

Under these circumstances, the real economic growth rate for 1982 is forcast to be only 2 to $3 \%$. According to the government's optimistic estimate at the initial period of 1982, the rate was expected to reach $5.2 \%$ but had to be adjusted down to $3.4 \%$ in October.

Being placed in these general economic conditions, iron and steel production activities stayed rather stagnant as the demands from domestic and international users remained inactive due to the worldwide recession. The inventory of steel materials at the wholesalers' level continued to increase coming into 1982 in spite of the completion of inventory adjustment at the end of 1981. The decrease in export of pipes and tubes for oil countries and the side effects of trade disputes on iron and steel between the United States and European countries tended to put brake for further exporters' efforts. Consequently the annual output of crude steel for 1982 appears to go under 100 million tons, the worst since 1972.

Despite many discouraging economic trends, improvement and progress in the field of iron and steel technology was vigorously pursued to meet increasing needs for rationalization even under the low capacity utilization rate of less than $60 \%$. Particularly automation and continuous operation of iron and steel making and rolling processes including improvement in continuous casting technology have been further emphasized for better material utilization, energy conservation and labor saving. Also much progress was observed in the comprehensive utilization of computers for integrated control of all manufacturing processes, development and installation of energy recovery facilities and environmental protection measures.

In terms of equipment investment, the industry made comparatively large expenditure as indicated in the estimated total of 1,092.4 billion yen which exceeds 802.5 billion yen of 1981 (on a construction basis) by $36.1 \%$ and shows steady and firm growth against generally slow and weak investment climate in industries in general. The active investment was mainly directed to modernization and energy saving works such as continuous casting, maintenance and reinforcement works. The investment was also made to meet new demands, such as construction of seamless pipe mills, surface treatment lines and continuous annealing lines as well as renovation of blast furnaces and rolling mills. The ratio of investment in energy saving facilities in the total equipment investment was $21.0 \%$ in 1982 comparing with $26.9 \%$ in the previous fiscal year.

\section{Technology and Facilities}

\section{Ironmaking}

Reflecting the trend toward construction of large volume blast furnace in recent 10 years, the number of blast furnaces with inner volume exceeding $4,000 \mathrm{~m}^{3}$ among the total 66 blast furnaces in Japan is 15,13 of which is in operation as of December, 1982. Considering the general low utilization rate of only 40 blast furnaces in operation, the large size blast furnaces are fully utilized. The following table shows the blast furnaces either blown in or out during 1982. Due to the low operation rate resulting from stagnant market, only 3 blast furnaces were blown in while 7 were blown out.

\section{(1) Blown-in Blast Furnaces}

\begin{tabular}{|c|c|c|c|c|}
\hline Company & Works & BF No. & $\begin{array}{l}\text { Month } \\
\text { blown } \\
\text { in }\end{array}$ & $\begin{array}{l}\text { Inner } \\
\text { volume } \\
\left(\mathrm{m}^{3}\right)\end{array}$ \\
\hline $\begin{array}{l}\text { Tippon Steel } \\
\text { Corp. }\end{array}$ & Kimitsu & No. 2 & Feb. & 2,884 \\
\hline $\begin{array}{l}\text { awasaki Steel } \\
\text { Corp. }\end{array}$ & Mizushima & No. 4 & Jan. & 4,323 \\
\hline umitomo Metal & Wakayam & No. 4 & Feb. & 2,610 \\
\hline
\end{tabular}
Industries, Ltd.

\footnotetext{
* Written in December 1982. (C) ISIJ 1983

** Ghief Secretary, The Joint Research Society, The Iron and Steel Institute of Japan, Otemachi, Chiyoda-ku, Tokyo 100.
} 
(2) Blown-out Blast Furnaces

\begin{tabular}{|c|c|c|c|c|}
\hline Company & Works & BF No. & $\begin{array}{l}\text { Month } \\
\text { blown } \\
\text { out }\end{array}$ & $\begin{array}{l}\text { Inner } \\
\text { volume } \\
\left(\mathrm{m}^{3}\right)\end{array}$ \\
\hline Nippon Steel & Sakai & No. 2 & March & 2,797 \\
\hline Corp. & Kimitsu & No. 3 & May & 4,033 \\
\hline & Muroran & No. 1 & Nov. & 1,245 \\
\hline & Hirohata & No. 3 & Nov. & 1,691 \\
\hline Kawasaki Steel & Mizushima & No. 1 & Jan. & 2,156 \\
\hline Corp. & Chiba & No. 2 & Aug. & 1,380 \\
\hline Sumitomo Metal & 1 Wakayama & No. 5 & Feb. & 2,700 \\
\hline
\end{tabular}

Industries Ltd.

The recent blast furnace operation performance is shown in Table 2. Both fuel ratio and coke ratio showed increasing tendency comparing with $461 \mathrm{~kg} / \mathrm{t}$ in fuel ratio and $423 \mathrm{~kg} / \mathrm{t}$ in coke ratio in 1979 , respectively, which indicated the lowest points. The Japanese iron and steel industry has been endeavoring reduction of fuel ratio with utmost efforts because of the extremely limited energy supply sources within the country. Since the second oil crisis it began to rely on energy sources other than oil and tried to reduce oil injection, resulting in gradual increase of fuel ratio. Nevertheless, the firms continued their efforts further to lower the fuel ratio. For example, No. $3 \mathrm{BF}\left(3,223 \mathrm{~m}^{3}\right)$ of Fukuyama Works of Nippon Kokan K. K. recorded $396 \mathrm{~kg} / \mathrm{t}$ monthly fuel ratio, thus breaking the critical line of $400 \mathrm{~kg} / \mathrm{t}$ in November, 1981 and Kawasaki Steel Corp. established the annual coke ratio of $458 \mathrm{~kg} / \mathrm{t}$ (from January to December, 1981) under all-coke operation at No. $6 \mathrm{BF}$ of Chiba Works.

The so-called " oil-less" blast furnace operation is vigorously pursued at each firm. Since August, 1982, Godo Steel, Ltd. changed No. 2 BF of Osaka Works to an oil-less type, all 40 blast furnaces in operation in Japan have become oil-less. Out of 40, 12 adopts tar injection while one uses pulverized coal and the remaining 27 employ all-coke operation.

No. $3 \mathrm{BF}\left(5,050 \mathrm{~m}^{3}\right)$ of Kashima Works, Sumitomo Metal Industries, Ltd. is now carrying out CTM (coal-tar mixed fuel) injection test following COM (coal-fuel oil mixed fuel) injection test completed at the end of 1981. Kobe Steel, Ltd. is also installing pulverized coal injection equipment at No. $2 \mathrm{BF}$ of Kakogawa Works $\left(3,850 \mathrm{~m}^{3}\right)$ and at No. $3 \mathrm{BF}$ of Kobe Works $\left(1,845 \mathrm{~m}^{3}\right.$, presently under relining). Kawasaki Steel Corp. in cooperation with Denka Engineering Co. is developing an original technique to inject pulverized coal and made a practical test at No. 2 BF of Chiba Works.

Along with the improvement in these operation and repairing technology, a campaign life of blast furnace is increasing. No. 3 BF of Kimitsu Works, Nippon Steel Corp. achieved a long life of 10 years and 8 months since blown in on September 13, 1971 and blown out on May 26, 1982. During this period, the No. $3 \mathrm{BF}$ recorded the total output of 32 million tons, the average productivity of $2.0 \mathrm{t} / \mathrm{m}^{3}$ and the average fuel ratio of $465 \mathrm{~kg} / \mathrm{t}$, demonstrating the long, steady and highly efficient operation.

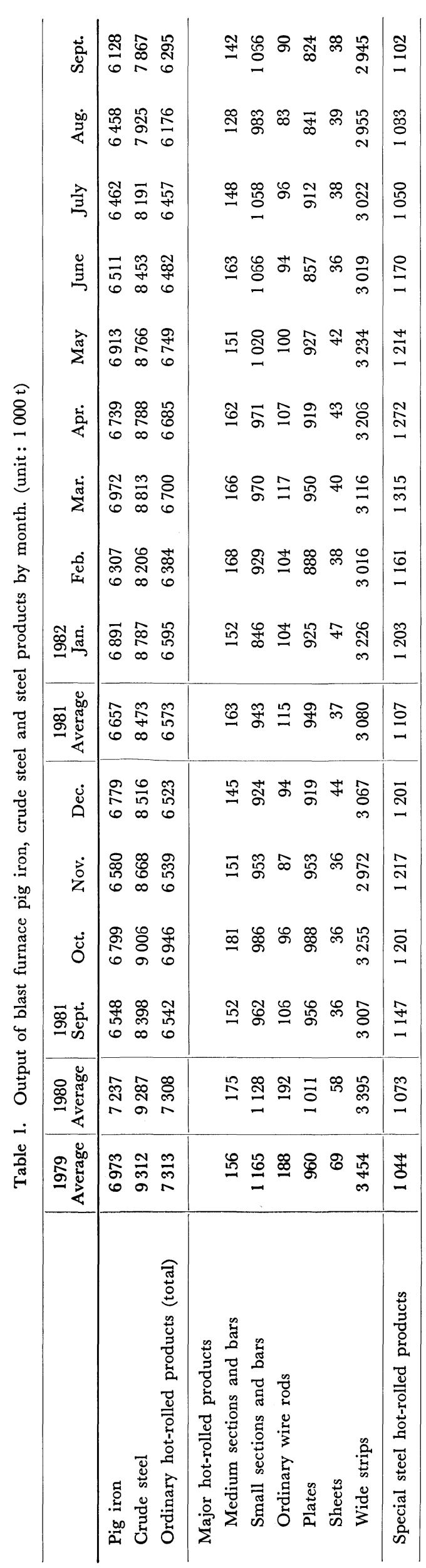




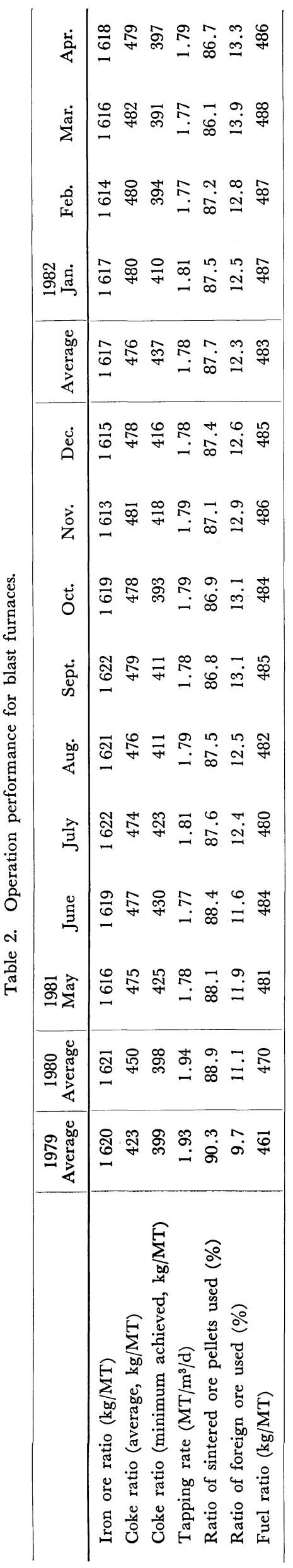

\begin{tabular}{|c|c|}
\hline 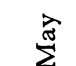 & 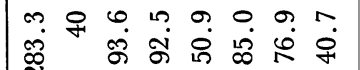 \\
\hline 晏 & 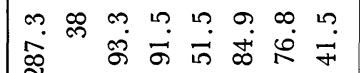 \\
\hline & 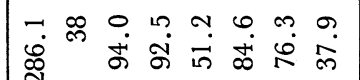 \\
\hline$\dot{0}$ & 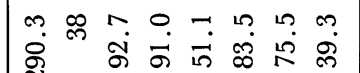 \\
\hline 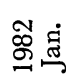 & 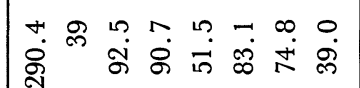 \\
\hline 总 & 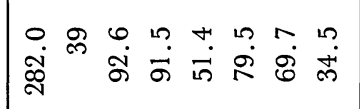 \\
\hline$\stackrel{\text { ٌ }}{ }$ & 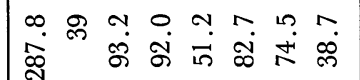 \\
\hline 宫 & 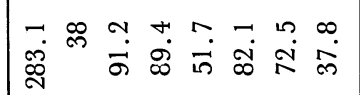 \\
\hline ठّ & 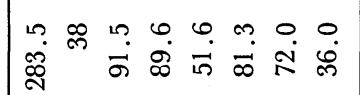 \\
\hline 莒 & 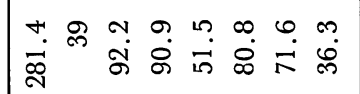 \\
\hline$\sum^{\infty}$ & 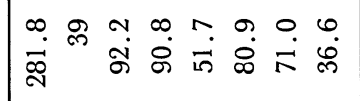 \\
\hline$\frac{2}{3}$ & 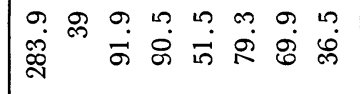 \\
\hline 总莺 & 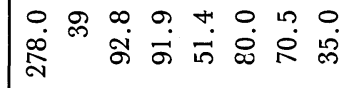 \\
\hline 总 & 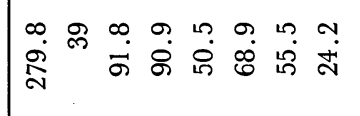 \\
\hline 嵌 & 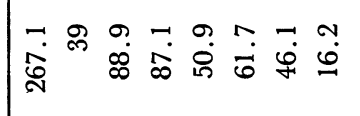 \\
\hline & 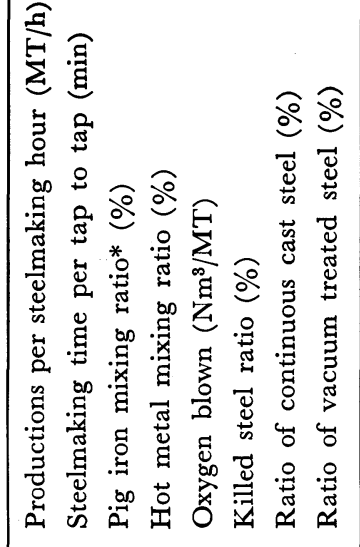 \\
\hline
\end{tabular}

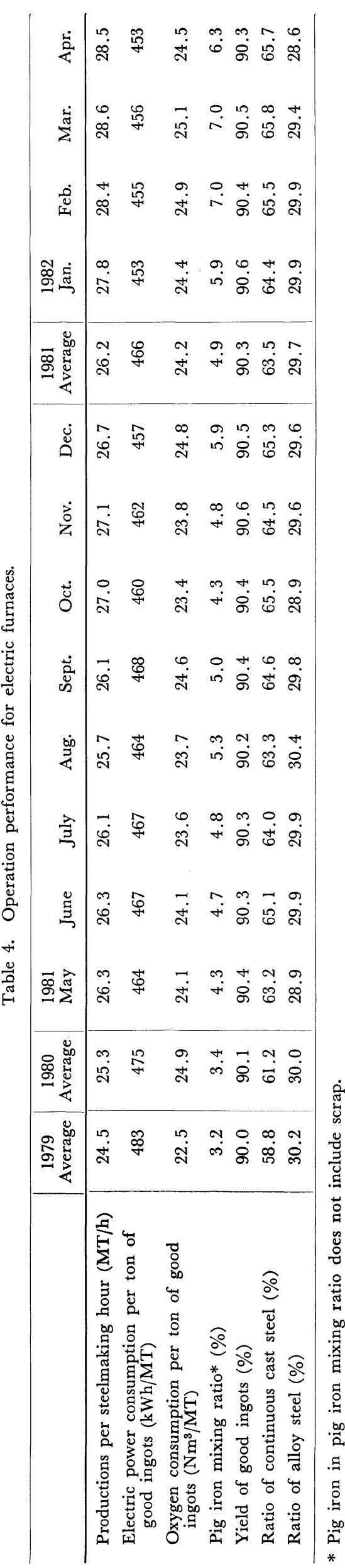


Iron and steel firms are also concerned to grasp the inner behavior of blast furnaces. Nippon Steel Corp. in cooperation with Toshiba Corp. developed BF top burden profile meter, while Kawasaki Steel Corp. developed an operation control data system for iron production. These new techniques are showing expected results. Chiba Works of Kawasaki Steel Corp. established the aggregate iron output of 100 million tons on June 21, 1982, following the records of Yawata Works, Nippon Steel Corp. in September, 1969 and Fukuyama Works, Nippon Kokan K. K. in March, 1979.

\section{Steelmaking}

The recent trends in steelmaking are the increase of the percentages of killed steel in all crude steel output and of continuously cast steel in all crude steel output together with improvement on ladle refining technology as shown in Table 3 on converter operation performance and Table 4 on electric furnace operation performance. These recent trends are described with several examples in the following chapters.

In the field of converter steelmaking, new refining methods of top and bottom blowing are replacing the conventional pure oxygen top blowing methods called LD, BOF, etc. Various firms are developing modified versions of this method. The new refining method consists of blowing of various gases from the bottom of LD converter in order to enhance the stirring force for better refining efficiency. Depending on the gas to be blown from the bottom, they are classified in two kinds. One employs pure oxygen while the other uses slowly active or inactive gas such as argon, nitrogen, carbon dioxide or mixed gas of these with oxygen. The volume of gas used and the blowing method varies from firm to firm, however.

Among many successful examples of modified converter operations, Nippon Steel Corp. is using combined pure oxygen top and bottom blowing refining so successfully that No. 2 Converter of No. 3 Steel Mill at Yawata Works poured 2,434 charges from Decem- ber 28, 1981 to April 22, 1982 in one campaign.

The above-mentioned good records owe to the improvement not only of refining, but also repairing techniques. For example, Kawasaki Steel Corp. developed flame gunning process in which mixed refractory and carbon powder is injected with pressurized oxygen for inner wall repairing.

Another example of technical progress in steelmaking is the development and the wide utilization of outof-furnace refining techniques for hot metal and molten steel not only by integrated steel works, but also by special steel makers for high grade steels. In order to manufacture highly clean steels such as extremely low phosphorous steel, some integrated steel works are trying steadily to obtain assurance of high quality, saving of ferro-alloys, improvement of yield of poured steel by the optimum combination of the processes of hot metal pretreatment, top and bottom blowing converter and ladle refining.

Ghita Works of Aichi Steel Works Ltd. and Chita Works of Daido Steel Co., Ltd., which are known as special steel makers, have respectively established an integrated process of arc electric furnace- $-\mathrm{LF}$ (ladle refining furnace)- $\mathrm{RH}$ (a type of vacuum degassing) - GG (continuous casting) for improvement of productivity, steel quality and materials and energy consumption.

One of new steelmaking technologies worth mentioning is the pilot plant test of continuous steelmaking using scrap as raw material. This test was conducted by Mitsubishi Heavy Industries, Ltd. as an entrusted project from Research Development Corporation of Japan (semi-public establishment) to industrialize a continuous steelmaking process earlier developed by National Research Institute for Metals. A pilot plant with monthly production capacity of $10,000 \mathrm{t}$ was constructed in the works of Shimizu Steel Mfg. Co. in Hokkaido and was put into test operation in May, 1981. In 1982 the test of $48 \mathrm{~h}$ continuous operation was successfully experimented. The process of this technology is illustrates in Fig. 1.

\section{Continuous Casting and Slabbing-Blooming}

In comparison with the conventional ingotmaking the continuous casting offers many advantages and

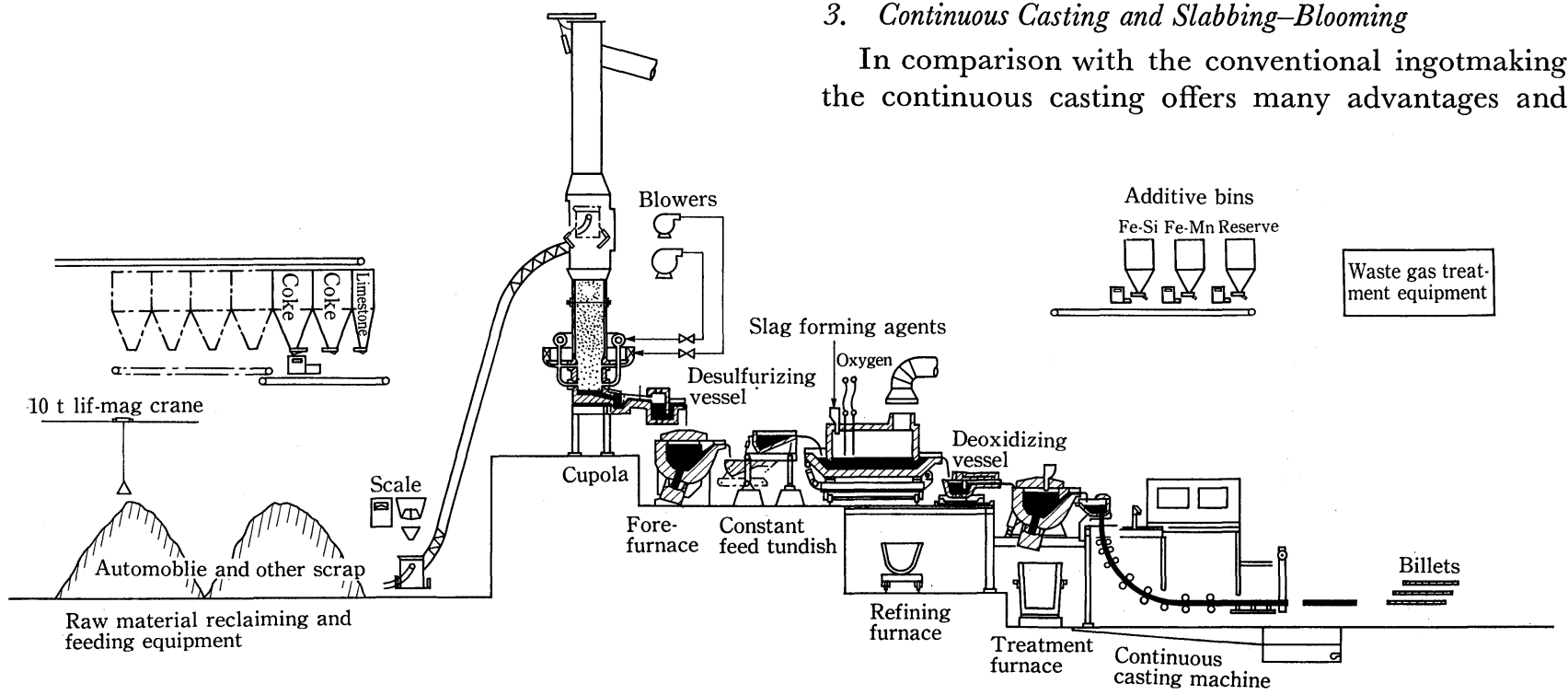

Fig. 1. The process of continuous steelmaking 
brings about improvement of yield, energy saving and better productivity. Thus, steel manufacturers throughout the world are actively constructing continuous casting facilities. Japanese firms have particularly shown enthusiasm to it and consequently the ratio of continuously cast semi-products in the total crude steel output in 1981 was pushed up to as high as $74.2 \%$. Taking into account the facilities to be installed in the near future, this ratio will exceed $80 \%$ in a few years.

Efforts are being made to increase the number of steel types and grades applicable to continuous casting. Development for change of mold width without stopping and continuous casting of different grades without stopping is also being carried out. New facilities put into operation since the end of 1981 are:

1) Continuous Casting Mill of Twin Type for Long Products (105,000 t) of No. 1 Steel Mill, Kimitsu Works, Nippon Steel Corp. (modification of slab continuous casting mill)

2) Straight and Bending Type Continuous Casting Mill $(200,000 \mathrm{t})$ of No. 2 Steel Mill, Kimitsu Works, Nippon Steel Corp.

3) No. 3 Continuous Casting Mill (152,000 t), Muroran Works, Nippon Steel Corp. for blooms and slabs.

4) Continuous Casting Mill for Seamless Tube Rounds (No. 5 Continuous Casting Mill) (70,000 t), Keihin Works, Nippon Kokan K. K.

5) No. 2 Continuous Casting Mill (175,000 t), Kure Works, Nisshin Steel Co., Ltd.

6) No. 2 Continuous Casting Mill (57,000 t), Osaka Works, Godo Steel, Ltd.

7) No. 2 Continuous Casting Mill (51,000 t), Toyohashi Works, Topy Industries Ltd.

8) Slab Continuous Casting Mill, Nagoya Works, Chubu Steel Plate Co., Ltd.

Another noticeable feature in this field is adoption of electro-magnetic stirrers to meet demands for better surface and homogeneous quality. In 1982 No. 4 Bloom Continuous Casting and No. 5 Continuous Casting Mills of Keihin Works of Nippon Kokan K. K. and Bloom Continuous Casting Mill of Funamachi Works of Nakayama Steel Works, Ltd. adopted the mold attached electro-magnetic stirring method.

Kawasaki Steel Corp. also developed mold attached electro-magnetic brake technique for prevention of non-metallic inclusions in continuously cast steel using electro-magnetic force and put it into trial operation on a commercial equipment at No. 5 Continuous Casting Mill of Mizushima Works. Sumitomo Metal Industries Ltd. recorded 1,129 charges amounting to $176,000 \mathrm{t}$ during $1,034 \mathrm{~h}$ (from June 9 to July 22, 1982) without stopping at its No. 2 Bloom Continuous Casting Mill of Wakayama Steel Works.

Looking at the field of slabbing, Kobe Steel, Ltd. developed a robbot for removing ingot surface defects and put it into use at No. 1 Steel Mill of Kakogawa Works. Other efforts are also being made for the purpose of yield increase and energy saving.

\section{Rolling}

The developments aiming at scaling up, speeding up, furthering continuous operation and energy saving are prominent in the field of rolling, too. The results of these efforts together with the help of process computers are contributing to the improvement of productivity and quality as well as reduction of unit consumption of energy.

With regard to the yield in plate rolling, ordered specification hitting rate in Kawasaki Steel Corp. recorded $95.2 \%$ at its plate mill in Mizushima Works in July, 1982, while Nippon Steel Corp. marked even better $95.6 \%$ at its plate mill in Kimitsu Works in September. As for prime product yield of wire rods, Nippon Steel Corp. achieved a theoretical optimum value of $99.3 \%$ in August, 1982 at its wire rod mill of Kimitsu Works.

Another trend in the rolling technology is well timed combination of steelmaking and rolling processes, such as hot direct rolling (HDR). Here, HDR means rolling of hot semi-products without cooling for conditioning. Oita Works of Nippon Steel Corp. has been using this method on a commercial basis since December, 1980 and recorded direct rolling rate of $84.2 \%$ in January, 1982. Even those steel works which are not currently using hot direct rolling or hot charge rolling method (HCR), which indicates rolling of hot semi-products after brief reheating without cooling for conditioning, are adopting plant layouts which will allow adoption of a combined continuous casting-rolling process when a continuous casting mill is installed. As an example Kure Works of Nisshin Steel Co., Ltd. modified its layout in such a way. Large section Mill of Sumitomo Metal Industries, Ltd.'s Kashima Steel Works completed a direct rolling practice of continuously cast slab for all sizes of wideflange beams.

The following continuous rolling facilities were put into operation in 1982. (Production capacity is expressed on a monthly basis.)

1) Continuous Descaling-Cold Rolling Mill (CDCM), Kimitsu Works, Nippon Steel Corp. (171,000 t)

2) CAPL Type Continuous Annealing Line, Nagoya Works, Nippon Steel Corp. (55,000 t)

3) Continuous Cold Rolling-CAPL Type Annealing Mill, Hirohata Works, Nippon Steel Corp. $(90,000 \mathrm{t})$

4) Continuous Annealing Mill, Kakogawa Works, Kobe Steel, Ltd. (45,000 t)

5) Continuous Electro-galvanizing Mill, Chiba Works, Kawasaki Steel Corp. (20,000 t)

6) Continuous Coating Mill (No. 1 GCL), Sakai Area Works, Nisshin Steel Co., Ltd.

7) Continuous Hot Dip Galvanizing Mill (No. 1 CGL), Sakai Area Works, Nisshin Steel Co., Ltd.

8) Continuous Annealing Mills for Stainless Sheets, Muroran Works and Hikari Works, Nippon Steel Corp.

New rolling mills put into operation in 1982 are shown below. Among these the first items is conspicuous in the investment amount and involves many 
technical innovations. (Production capacity is expressed on a monthly basis.)

1) Hot Strip Mill, Yawata Works, Nippon Steel Corp. $(380,000 \mathrm{t})$

2) Wire Rod Mill, Osaka Works, Godo Steel, Ltd. (50,000 t)

3) Rod Mill, Funamachi Works, Nakayama Steel Works, Ltd. (50,000 t)

In addition to the above-mentioned technical advancements, strenuous efforts are being made to develop new welding techniques and heat treatment techniques as well as the developments of new products. However, their details are omitted here for saving space of this article.

\section{Measuring and Controlling}

Computers are extensively used in steel works for various purposes such as material flow control, quality control, energy control and centralized information control. The process control data system mentioned earlier in Section II. 1. is one example of computer utilization.

With respect to process control, the BF top burden profile meter (No. 1 BF, Muroran Works, Nippon Steel Corp.) described in Section II. 1., high precision rediation thermometer for temperature measurement inside B.F. (Nippon Steel Corp.) and other new measuring techniques have been developed and adopted in commercial operation. Another newly developed technique is roughing roll automatic width control in hot rolling (Sumitomo Metal Industries, Ltd.)

Along with the increase of demands for high grade steels, the needs of continuous processing, labor saving and stricter quality assurance must be met. In order to meet such requirements, highly efficient and precise measuring and controlling techniques are necessary. Hence, many new techniques have been developed and become available for commercial purposes. One of the examples is the supersonic flaw detector for rods developed and operated by Kobe Steel, Ltd. Wakayama Steel Works of Sumitomo Metal Industries, Ltd. developed in-line flatness meter for cold-rolled sheets, while Tokyo Works of Mitsubishi Steel Mfg. Co., Ltd. developed eddy current revolving probe and flat bar automatic flaw detector consisting of segment coils. Amagasaki Works of Daido Steel Sheet Corp. developed continuous wet coating thickness meter for continuous sheet coating by using Compton effect.

\section{Technology Transfer and Technical Coop- eration}

In postwar days the Japanese iron and steel industry imported the world's most advanced technology from industrialized countries to raise its own technical level. As a result of these modernization efforts, presently the industry has acquired internationally appraised iron and steel technology. This transformation is manifested in the contents of technological transfer to and from Japan. The previous pattern of heavy reliance on technical imports was completely reversed to the favorable balance of imports and ex- ports. In 1980, 332 items were exported with the income of 17.9 billion yen comparing with 329 worth 17.7 billion yen in 1979, while 293 items worth 8 billion yen were imported in comparison with 325 worth 5.8 billion yen in 1979. The exports in 1955 to 1965 were mainly directed to developing countries and were of small scale, but 20 years later the exports to advanced countries have been made in considerable scale and requests for Japanese firms' participation in large construction projects have increased. Particularly in recent years, requests for plant and equipment prognosis, operation guidance and other technical services are increasing.

Technological imports and exports in 1982 are summarized in Tables 5 and 6. As shown in these tables, Japanese technology is exported to all areas of the world including both advanced and developing countries and the contents vary extensively from large scale projects to a specific process in wide range of iron and steel making operations. These exports are extended in the form of patent licensing, know-how contracts, engineering, operation guidance training, etc.

The number of imported technology in 1982 was 17 items and they were introduced from the United States or European countries as shown in Table 6 . The imported items are mainly concerned to the downstream processes relating to new installation of seamless pipe mills and surface treatment processes for autobody sheets. Such trend is expected to continue further.

\section{Effective Utilization of Material, Energy Conservation and Replacement of Oil as Fuel}

Since the iron and steel industry is a large energy consuming industry in Japan using approximately $15 \%$ of total energy consumption in the country, it is understandable that research and development of heat economy technology is of utmost importance.

Looking at the consumed energy components for 1981 in terms of real heat generating standard and the estimated statistics, 518 trillion kcal (15\% of total national consumption-equivalent of 57.52 million $\mathrm{k} l$ of oil) consists of $75 \%$ of coal and its derivatives, $7 \%$ of oil and $18 \%$ of purchased electricity. (Amount of sales of in-works generated gas to steel-utility cooperative steam generators is included in coal and deducted from purchased electricity.) The energy consumption in 1953 was 649 trillion kcal (equivalent to 72.13 million $\mathrm{k} l$ of oil), $61 \%$ of which come from coal and its derivatives, $21 \%$ from oil and $18 \%$ from purchased electricity. Comparing these figures, much improvement was noticed in energy conservation and less dependence on oil. This trend to so-called " oilless" operation is still proceeding. The ratio of oil as fuel has decreased from $16 \%$ in 1978 to $14 \%$ in 1979 and down to $7 \%$ in 1982. These figures show how hard steel firms have been trying to shift from oil to intra-works generated gas or LNG. In terms of energy consumption per ton of crude steel, putting the real unit energy consumption of 1973 as 100 , that 
Table 5. Content of technology exports.

\begin{tabular}{|c|c|c|c|}
\hline \multicolumn{2}{|r|}{ Description } & $\begin{array}{c}\text { Number } \\
\text { of } \\
\text { exports }\end{array}$ & \multirow[t]{2}{*}{ Importing country } \\
\hline (A) & $\begin{array}{l}\text { Raw } \\
\text { materials, } \\
\text { Ironmaking }\end{array}$ & & \\
\hline 1) & Coke & 4 & $\begin{array}{l}\text { Yugoslavia, Venezuela, Italy, } \\
\text { Argentina }\end{array}$ \\
\hline 2) & Pellet & 2 & Bahrain, Chile \\
\hline 3) & Iron Pig & 6 & $\begin{array}{l}\text { The Netherlands, Korea, } \\
\text { Argentina, U.K. }\end{array}$ \\
\hline (B) & Steelmaking & & \\
\hline 1) & Converter & 11 & $\begin{array}{l}\text { Australia, U.S.A., U. K., France, } \\
\text { Canada, Italy }\end{array}$ \\
\hline 2) & $\begin{array}{l}\text { Electric } \\
\text { furnace }\end{array}$ & 6 & $\begin{array}{l}\text { U.S.A., Malaysia, Venezuela, } \\
\text { Indonesia, Republic of South } \\
\text { Africa }\end{array}$ \\
\hline 3) & $\begin{array}{l}\text { Continuous } \\
\text { casting }\end{array}$ & 21 & $\begin{array}{l}\text { U.S.A., Indonesia, Algeria, } \\
\text { Australia, France," Luxemburg, } \\
\text { Canada, U. K., Belgium, Italy }\end{array}$ \\
\hline 4) & $\begin{array}{l}\text { Ladle } \\
\text { refining }\end{array}$ & 4 & $\begin{array}{l}\text { F. R. Germany, U.S.A., The } \\
\text { Netherlands }\end{array}$ \\
\hline (C) & $\begin{array}{l}\text { Plastic } \\
\text { forming and } \\
\text { other fabri- } \\
\text { cation pro- } \\
\text { cesses }\end{array}$ & & \\
\hline 1) & $\begin{array}{l}\text { Steel bars, } \\
\text { Wire rods }\end{array}$ & 4 & U. K., Brazil, Philippine \\
\hline 2) & Steel pipes & 2 & U.S.A., Australia \\
\hline 3) & Steel plates & 10 & $\begin{array}{l}\text { France, Norway, Australia, } \\
\text { Belgium, Finland, U.S.A., D.D.R., } \\
\text { Argentina, Brazil }\end{array}$ \\
\hline 4) & $\begin{array}{l}\text { Surface } \\
\text { treatment }\end{array}$ & 6 & $\begin{array}{l}\text { Malaysia, Thailand, Nigeria, } \\
\text { Haiti, Nepal }\end{array}$ \\
\hline 5) & $\begin{array}{l}\text { Heat } \\
\text { treatment }\end{array}$ & 3 & U.S.A., France, F. R. Germany \\
\hline 6) & $\begin{array}{l}\text { Processing, } \\
\text { forming }\end{array}$ & 2 & Indonesia \\
\hline 7) & Welded rod & 1 & Taiwan \\
\hline 8) & In general & 3 & Indonesia, Mexico, U.S.A. \\
\hline (D) & $\begin{array}{l}\text { Iron and } \\
\text { steel works } \\
\text { in general }\end{array}$ & 13 & $\begin{array}{l}\text { Indonesia, Spain, U.S.A., France, } \\
\text { New Zealand, Italy, Australia, } \\
\text { Argentina }\end{array}$ \\
\hline
\end{tabular}

\section{* Companies responded to the inquiry.}

Kawasaki Steel Corp.; Kobe Steel, Ltd.; Godo Steel, Ltd.; Nippon Steel Corp.; Sumitomo Metal Industries, Ltd. ; Daido Steel Co., Ltd. ; Tokyo Steel Manufacturing Co., Ltd. ; Nisshin Steel Co., Ltd.; Nippon Metal Industry Co., Ltd.; Nippon Kokan K.K.; Yodogawa Steel Works, Ltd.

for 1981 was 86.6, indicating effectiveness of energy conservation efforts.

Major energy consuming fields in iron and steel processes are sintering, coking, ironmaking, steelmaking, and rolling. The energy saving efforts in each of these fields are outlined as follows.

(1) In the sintering process, major energy conservation measures are combustion control of furnace, recovery of waste heat from cooler and sensible heat recovery from sintered ore. As a good example of the recovery of waste heat, Sumitomo Metal Industries, Ltd. applied latter measures into effect in all of its works during 1981 to 1982 and developed a waste
Table 6. Content of technology imports.

\begin{tabular}{|c|c|c|c|}
\hline & Description & $\begin{array}{c}\text { Number } \\
\text { of } \\
\text { imports }\end{array}$ & Exporting country \\
\hline (A) & $\begin{array}{l}\text { Raw materials, } \\
\text { ironmaking }\end{array}$ & & \\
\hline 1) & Pig iron & 1 & U.S.A. \\
\hline (B) & Steelmaking & & \\
\hline 1) & Converter & 1 & The Netherlands \\
\hline 2) & $\begin{array}{l}\text { Continuous } \\
\text { casting }\end{array}$ & 2 & Sweden, F.R. Germany \\
\hline (C) & $\begin{array}{l}\text { Plastic forming } \\
\text { and other fabri- } \\
\text { cation processes }\end{array}$ & & \\
\hline 1) & $\begin{array}{l}\text { Surface } \\
\text { treatment }\end{array}$ & 3 & U.S.A. \\
\hline 2) & $\begin{array}{l}\text { Mechanical } \\
\text { processing }\end{array}$ & 6 & $\begin{array}{l}\text { France, U.S.A., } \\
\text { F.R. Germany, Switzerland }\end{array}$ \\
\hline 3) & $\begin{array}{l}\text { Processing, } \\
\text { forming }\end{array}$ & 1 & U.K. \\
\hline 4) & $\begin{array}{l}\text { Magnetic defect } \\
\text { detection }\end{array}$ & 3 & F.R. Germany \\
\hline
\end{tabular}

* Companies responded to the inquiry.

Kobe Steel, Ltd.; Nippon Steel Corp.; Sumitomo Metal Industries, Ltd. ; Chubu Steel Plate Co., Ltd. ; Mitsubishi Steel Mfg. Co., Ltd.; Yodogawa Steel Works, Ltd.

gas heat recycling process in which the waste gas previously released to the air after recuperators is recycled to the sintering furnace. This recycling process was commercially adopted at No. 3 Sintering Mill of Kokura Steel Works.

(2) Combustion control of cokeoven and coke dry quenching (CDQ) are typical energy conservation methods taken in cokeovens, particularly the CDQ showing to be a very effective measure.

Nippon Steel Corp. developed a technique to recover sensible heat from cokeoven gas (COG) with recycling organic agent and to replace it with steam for preheating of mixed gas for coking fuel and adopted this method for the operation of No. 4 Cokeoven of Nagoya Works in March, 1982. In addition to the COG sensible heat recovery, the company developed coal humidity control system to maintain the humidity of charged coal at a fixed value by combining the above-mentioned technique with recovery of waste gas from combustion. The commercial machines are being constructed for Nos. 1 and 2 Cokeovens of Oita Works and expected to start operation in the fall of 1983. As a result of these efforts, Nippon Steel Corp. reached the low coke dry quenching heat consumption of $606 \mathrm{kcal} / \mathrm{kg}$ in average per quarter of 1982.

In order to enhance heat efficiency of COG in the oil-less steel works, Kyodo Sanso Co., Ltd. and Sumitomo Metal Industries, Ltd. jointly developed the facilities to manufacture high purity hydrogen from COG and installed a practical unit at Kyodo Sanso's Wakayama Works located in the site of Wakayama Steel Works.

(3) The blast furnace process which uses approximately $50 \%$ of total energy used in a steel works has 
a great impact on the energy saving. Waste heat recovering methods in ironmaking include recovery of high BF top pressure energy by using a turbine, of heat of stave cooling-water, of heat from hot stove waste gas and of sensible heat in BF slag. In this field the following new power generators were installed and put into operation in 1982.

1) $\mathrm{BF}$ gas turbine-steam turbine combined cycle generators, Kamaishi Works, Nippon Steel Corp.

2) Hydro-electric generator using BF cooling water, Mizushima Works, Kawasaki Steel Corp.

3) Dry type BF top pressure generator, Kokura Steel Works, Sumitomo Metal Industries, Ltd.

(4) In the steelmaking process, energy conservation efforts include improvement of converter gas recovery rate and wider utilization of continuous casting. Studies are made to use sensible heat of converter slag which has been abandoned hitherto. As for recovery of converter gas, No. 3 Steel Mill of Chiba Works, Kawasaki Steel Corp. recorded 138.3 $\mathrm{Nm}^{3} / \mathrm{t}$ of crude steel (equivalent to $2,000 \mathrm{kcal} / \mathrm{Nm}^{3}$ ), in June, 1982. Scrap preheating devices using recycled hot waste gas from electric furnaces have been commercially used by a few works since 1978 . Increasingly large number of firms are installing these devices and in 1981 Sanyo Special Steel Co., Ltd., Topy Industries Ltd. and others installed them.

(5) Typical energy saving measures in the rolling process are the modification of heat pattern in a reheating furnace, double insulation of skids and other furnace insulations, automatic control of air-fuel ratio, recovery of exhaust gas heat from reheating furnaces, hot charged rolling (HCR) and hot direct rolling (HDR) described previously. With increasing utilization of these measures much improvement has been achieved in fuel unit consumption. For example, because of the progress in HDR, Nippon Steel Corp. recorded $166 \times 10^{3} \mathrm{kcal} / \mathrm{t}$ of total energy for the processes from continuous casting to reheating at its Sakai Works in August. As for unit consumption of fuel for a reheating furnace, Muroran Works of Nippon Steel Corp. achieved in July $94 \times 10^{3} \mathrm{kcal} / \mathrm{t}$, the first record in Japan below $100,000 \mathrm{kcal} / \mathrm{t}$.

(6) In other fields such as transportation, energy saving efforts are noticed in construction of low energy consumption type raw materials carriers and improvement of accommodation facilities for large size carriers to reduce bunker oil requirement.

The Ministry of International Trade and Industry started a system named "Subsidy for Development of Common Basic Energy Technology to Replace Oil" and designated the development of fusion smelting and integrated recovery of sensible heat of liquid slag as projects covered by this system. Consequently integrated steelmakers, ferroalloy makers, special steel makers and non-ferrous smelters set up "Research Association for Smelting Process Advancement" in September, 1982.

Owing to the efforts already described, the Japanese iron and steel industry has shown as one of the world's best energy conservation records holders. However, the measures centered around reinforce- ment of energy consumption control and improvement of production processes with little investment can not go over certain limitations. For further efforts to reduce energy consumption, attentions must be paid on various factors involving a long period of development works and the accompanied investment which may end up in diminishing returns. Some of the remaining tasks are development of effective facilities for recovery of sensible heat from slag or hot rolled steels and that of ironmaking methods of structurally less energy consuming type. Development and commercial application of these technologies will surely have to need an extensive investment.

\section{Environment Protection}

Details of various regulations, standard values, measures and others relating to environmental protection were reported in " Production and Technology of Iron and Steel in Japan during 1982 " published in Transactions ISIJ, 22 (1982), No. 4. Accordingly, the developments since the issue of this report will be mentioned as follows.

The subsidy from The Fund for Development of Environmental Protection Technology in Iron and Steel Industry was extended to 19 items at the expense of 295 million yen by 1981 and 22 items of 200 million yen by 1982 .

With respect to $\mathrm{NO}_{x}$, the average daily standard remains as 0.04 to $0.06 \mathrm{ppm}$, but stricter standards are applied to Tokyo Area, Yokohama Area and Kawasaki Area as reported previously. To meet these requirements and reach the prescribed level of gross $\mathrm{NO}_{x}$ contents by 1985, various programs are under study. As for the soot and smoke, the discharge standard was modified to a stricter one in June, 1982. The iron and steel firms are trying various methods to meet this standard taking into consideration the increasing use of coal.

In the prevention of water contamination, the industry has been able to achieve nearly $100 \%$ of recirculation rate and fully satisfy the regulations, as previously reported.

Recycling of BF slag as a Portland cement ingredient and road materials is actively promoted. Comparing with the recycling rate of $98.1 \%$ in 1980 , the rate for 1981 was $99.4 \%$, nearly $100 \%$. This improvement owes partly to the establishment of Japanese Industrial Standard JIS A5011 for coarse aggregates and JIS A5012 for fine aggregates which was mentioned in the previous report also.

Looking at the material recycling rate for converter slag, the rate is improving gradually from $64.6 \%$ in 1980 to $70.8 \%$ in 1981, but this is not comparable to that for the BF slag. Under these circumstances, the industry is preparing "Design and Application Manual on Asphalt" and is making investigation and tests on the utilization of converter slag as a road material.

The usage of the converter slag as soil improvement agent has become available due to the revision of Fertilizer Control Law in December 1981. Under the revised regulations, the converter slag is 
classified as a special fertilizer.

From the above-mentioned review, it is clear that the Japanese iron and steel industry has got sufficient environmental protection technology to meet public regulations. By doing so the industry continues to recognize its grave concern to its social responsibility and to find ever better technology.

\section{Lecture Meetings and Seminars}

\section{Semi-annual Lecture Meeting}

This meeting is the most important activity of ISIJ and held in spring in Tokyo Area and in autumn in some local town.

\section{The 103rd Lecture Meeting}

It was held in Tokyo Institute of Technology on April 1 to 3, 1982 and 663 papers were presented, 228 on ironmaking, 179 on steelmaking, 122 on plastic working and other fabrication processes, 228 on properties of iron and steel, and 31 on poster sessions, including 5 symposia on the themes as follows:

1) Oilless Operation Technique of Blast Furnace

2) Developments of New Steelmaking Processes in BOF

3) On the Manufacturing Processes and Properties of $\mathrm{Zn}$ and $\mathrm{Zn}$-alloy Plated Steel Sheets

4) Progress in Free Machining Steel Technology

5) Ductile Fracture in Steel Structure

Two prize earner's lectures were also given.

\section{The 104th Lecture Meeting}

It was held in Hokkaido University on September 27 to 29,1982 , and 844 papers were presented, 179 on ironmaking, 195 on steelmaking, 183 on plastic working and other fabrication processes, and 287 on properties of iron and steel, including 5 symposia on the themes as follows:

1) The Behaviour of $\mathrm{Si}$ in the Blast Furnace

2) Quality of Continuously Cast Slabs and Blooms and Mechanical Properties of Steels at High Temperatures

3) Recent Technology for Seamless Pipe Production

4) Application of Stochastic Theory to Steel Corrosion

5) Fundamentals and Application of Controlled Rolling and Controlled Cooling Processes

In addition, Dr. B. Trentini, as a Yukawa Memorial Lecturer, gave a lecture titled "The Tendency in Metallurgical Science and Technology in FranceThe Functions of IRSID and ATS ".

This meeting was followed by a few plant visits in Hokkaido Prefecture.

\section{Nishiyama Seminar}

The seminars are organized for the re-education of technical staffs and researchers keeping them abreast of recent technical innovations. Each seminar has a specific topics selected from various fields of iron and steel technology, and lecturers are chosen from the industry as well as from academics.

The seminars are held four times per year in Tokyo and some local towns. The topics taken up in 1982 are as follows:

1) Progress of the Energy Saving Technology in the
Steel Industry

2) Development of the Powder Metallurgy of Iron and Steel

3) Recent Approach in the Fatigue Failure Test of Steel

4) Recent Development of Plate Manufacturing and Quality of Plate

\section{Shiraishi Seminar}

This seminar was inaugurated in 1982 owing to the fund donated by Nippon Kokan K. K. for commemoration of its 70 year aniversary and was named after late Mr. M. Shiraishi, founder of this company. Its object is dissemination of knowledge for not only technical but also business personnel who are woking in the steel industry and the related industries. The themes are not selected from iron and steel technology in proper, but out of the related industrial technologies which are contributing to the progress of the steel industry.

The first theme was " Recent and Future Application of Computers in the Steel Industry." From now on this seminar is to be held in Tokyo and some local town once a year.

\section{Iron and Steel Engineering Seminar}

This seminar is intended to career education of young diploma-engineers, emphasis being put on basic theories of metallurgy. It is held once a year by reserving a hotel for lectures as well as for lodging. Lectures are divided into three sections, namely ironmaking, steelmaking and material science. This year it was held in August 23 to 28, with 138 participants.

\section{International Activities}

\section{The 5th Japan-Germany Seminar}

The seminar met at the hall of German Iron and Steel Institute (VDEh) in Düsseldorf on May 3 and 4, 1982, with 13 Japanese members led by Prof. K. Mori and 80 German counterparts headed by Dr. A. Randak.

10 papers each from Japanese and German participants were presented. This presentation was followed by discussion on BF ironmaking, BF mathematical model analysis, hot metal treatment, thermal transfer phenomena and ladle refining under the two themes of Actual Problems of Hot Metal Production and Melting of Solids in Iron and Steel Production.

As for the postseminar tour, one university and 4 steel works were visited by Japanese members.

\section{The 2nd Japan-Venezuela Symposium}

This symposium was held at Keidanren Kaikan, Tokyo, on June 23 and 24, 1982. 9 papers from Japanese participants and 8 from Venezuelan participants were presented. Lectures and discussion centered on rolling theory, pipe manufacturing technology, quality control, technological transfer, problems in technical cooperation, training of personnel and metallurgical engineering education in universities. 14 members led by Dr. A. Gamboa, honorable leader, and Dr. J. C. Ohep, leader, participated from Venezuela. Prior to and following the seminar, the Venezuelan participants visited 1 university, 2 research in- 
stitutes and 5 steel works.

3. The 7th International Conference on Vacuum Metallurgy

The conference met at Keidanren Kaikan, Tokyo, for 4 days from November 26 to 30, 1982, being divided into 2 sections, namely, Special Meltings and Metallurgical Coatings.

(1) Special Meltings

78 papers consisting of 28 from Japanese researchers and 50 from the researchers of other 11 countries were presented in 25 session meetings on vacuum metallurgy, ladle refining, plasma technology and others.

\section{(2) Metallurgical Coatings}

99 papers consisting of 54 from Japanese researchers and 45 from 14 other countries were presented in 15 session meetings on superconductors and related films, plasma spraying, electron beam coating amorphous films and others.

The total number of participants was 415 including 298 from Japan and 117 from abroad. Following the conference, the foreign participants visited 3 steel works.

\section{Activities of Various Research Societies}

\section{Joint Research Society}

18 committees and 18 subcommittees of the Joint Research Society are conducting joint researches on iron and steel manufacturing technology as the joint undertaking of steel firms. The activities in 1982 are briefly introduced below. For further details, refer to "Activities Report of ISIJ for 1982 " published in Tetsu-to-Hagané, 69 (1983), No. 9, in Japanese.

\section{Ironmaking Committee}

The 60th and 61st meetings were held to discuss the following themes:

1) Effects of Coke Properties in BF Operation

2) Application of Sensor Data in BF to Commercial Operation

3) Application of Sensor Data in Sintering to Commercial Operation

\section{Coke Committee}

The committee held the 24th and 25th meetings on the following themes:

1) Evaluation of and Future Measures for Non or Weak Coking Coal

2) Recent Decrease in Distillation Energy for Cokeoven

3) Trends, Gurrent State and Future of Manning, Automation and Mechanization of Coke Division

\section{Steelmaking Committee}

The 81 st, 82nd and 83rd meetings were held to discuss:

1) Quality Improvement Technology for Bloom and Billet Continuously Cast Semi-products (Mainly on Improvement of Solidification Structure)

2) Enlargement of Steel Grades Applicable to Continuous Casting with Utilization of Secondary Refining (including Ladle Refining)

3) Pouring Time Rate Improvement for Continuous Casting Equipment (Prevention of Operational
Accidents and Damages, Width Change, Increase of One Lot Weight in Connection with Chemistry and Size, Shortening of Idle Time by Matching of Refining and Casting, etc. as Examples of Ways to Improve Continuous Casting Technology)

\section{Electric Furnace Committee}

The committee held the 19th and 20th meetings on the following subjects:

1) Quality Improvement of Electric Furnace Steel

2) Energy Saving in Electric Furnace Operations

3) Refractories for Electric Furnace

\section{Special Steel Committee}

The 67 th, 68th and 69 th meetings were held to discuss :

1) Improvement of Refining of High Alloy Steel (including Stainless Steel)

2) Problems and Measures for Refractories in Ladle Refining

3) Quality Improvement of Stainless Steel by Advancement of Steelmaking Technology (Secondary Refining, Continuous Casting, Ingot Making)

4) Improvement of Electric Furnace Operation (Better Utilization of Materials, Energy Conservation, Productivity)

5) Quality Improvement of Low Alloy Steel by Advancement of Steelmaking Technology

6) Improvement of Secondary Refining Operation (Stainless Steel, High Alloy Steel, etc.)

\section{Steel Plates and Sheets Committee}

The committee consisting of 4 subcommittees conducted the following activities:

(1) Blooming and Slabbing Subcommittee

The 54th and 55th meetings were held on the following themes:

1) Current State of Blooming Yield and Improvement Measures

2) Energy Saving and Innovative Measures in Blooming Mill

(2) Plates Subcommittee

The 53rd and 54th meetings met to study:

1) Labor Productivity

2) Quality Assurance

(3) Hot Strip Subcommittee

The subcommittee held the 36 th and 37 th meetings on the following themes:

1) Water Supply Facilities and their Operation

2) New Facilities and Modification of Facilities

(4) Cold Strip Subcommittee

The 35 th and 36 th meetings were held on the following themes:

1) Modification of Facilities and State of Modification

2) Thickness and Shape of Sheets

Starting in 1982, the subcommittee organized reversible mill visits and the first one was held at Nisshin Steel Co., Ltd., and the second at Daido Steel Sheet Mfg. Co., Ltd.

\section{Sections and Wire Rods Committee}

The committee consists of 3 subcommittees, each conducting following activities, respectively: 


\section{(1) Large Sections Subcommittee}

The 35th and 36th meetings were held on the following themes:

1) Gurrent State of and Future Measures for Energy Saving in Soaking Pit, Particularly on Hot Charge and Direct Rolling

2) Current State of a Unit Consumption of Roll and Reduction Measures

As a part of the activities, the subcommittee prepared "Large Section Steel Mill Layout Data in Japan ".

(2) Medium and Small Sections Subcommittee

The 52nd and 53rd meetings were held on the following themes:

1) Accessories of Rolling Mill

2) Current State of and Improvement Measures for Sizing Accuracy

3) Current State of and Improvement Measures for Yield

4) Roll Shift and Caliber Change

At the 52nd meeting, an invited lecture was presented on "Measurement of Diameter of Wires and Rods in Hot Rolling ".

(3) Wire Rods Subcommittee

The 53rd and 54th meetings were held on the following themes:

1) Roll Shift and Caliber Change

2) Automation and Computer Utilization of Rolling Process

\section{Steel Pipes and Tubes Committee}

The committee held the 38th and 39th meetings to receive reports on the common theme of "Process Control and Quality Control by Using Computers" on two aspects of "Business Computers" and "Process Computers".

The two subcommittees of this committee conducted the following activities, respectively.

(1) Seamless Pipe Subcommittee

The 30th and 31st subcommittee meetings were held to discuss:

1) Improvement of Yield (on Mannesmann Type Mills)

2) Threading Technique (on Mannesmann Type Mills)

3) Analysis of Downtime in Rolling Works (on Mannesmann Type Mills)

4) Cold Rolling Processing Technique (on Hot Extrusion, Cold Drawing)

5) Investigation on State of Finishing and Assorting of Hot Extrusion Material (on Hot Extrusion, Cold Drawing)

6) Finishing and Assorting of Cold Forming Stock (on Hot Extrusion, Cold Drawing)

(2) Welded Pipe Subcommittee

The subcommittee held the 30 th and 31 st meetings on the following themes:

1) Cost Reduction of Straight Welding Pipe Mills (on Electric Seam Welding and Butt Welding)

2) NDI Facilities (on Electric Seam Welding and Butt Welding)

3) Gutting and Turning in Finishing and Sorting (on Electric Seam Welding and Butt Welding)
4) Panel Discussion on High Toughness Line Pipe Manufacturing Technology (on Electric Seam Welding and Butt Welding)

5) Finishing and Inspection Facilities of Electric Seam Welding and Butt Welding Pipe Mills

6) Management and Training for UOE Mill Works and Subcontractors' Works

7) Standardization of Secondary Processing Works (on Arc Welded Pipe)

8) Specification Conscious Operational Method and Efficiency of Secondary Products Making (on Arc Welded Pipe)

9) Roll Change Time and Material Flow (on Arc Welded Pipe)

\section{Rolling Theory Committee}

The 71st, 72nd and 73rd meetings received 66 papers on Crown Control for Plates, Asymmetric Rolling Theory, Plasticity Theory for Mandrel Rolling and others. The committee also published "Review of Activities of Rolling Theory Committee" to introduce the research papers presented in the past 5 years at the committee meetings.

\section{Heat Economy Technology Committee}

The 70th and 71st meetings were held in 1982. At the 70th meeting, invited lectures were presented as the 70th anniversary program in addition to the discussion on the following themes:

1) Prospective Pattern of Iron and Steel Industry in Terms of Energy

2) Preheating of Scrap

3) Pulverized Coal Utilization

The committee also prepared periodical reports, "List of Energy Saving Facilities of 1981" and "Energy Balance (Integrated and Non-integrated Steel Works)", and published "Coping with EnergyReview of Activities of Heat Economy Technology Committee" in Japanese for the 70th anniversary.

Working Group on Heat Transmission in Reheating Furnace established in April, 1981 completed the assigned research and prepared a report. On the other hand, a new working group on Basic Technology of Exhaust Heat Recycling was established in April and is expected to conduct its research for a year and half.

\section{Refractories Committee}

The 31 st and 32nd meetings received 32 research papers on the following subjects:

1) Refractories for BF and Hot Stove

2) Refractories for Hot Metal Pretreatment, Trough Material and Heating Furnace

3) Refractories for Converter

4) Refractories for Ladle

\section{Instrumentation Committee}

The 80th, 81st and 82nd meetings received following research papers:

1) Measurement in Ironmaking: 17 papers

2) Measurement in Steelmaking: 11 papers

3) Measurement in Rolling: 25 papers

4) Measurement in Energy Facilities: 3 papers

5) Measurement for Product Inspection: 15 papers

6) Improvement of Instrumentation Technology and Reports on New Technology: 16 papers 
7) Others: 9 papers

13. Quality Gontrol Committee

The following themes were examined in the 46th and 47 th meetings.

1) Problems in Inspection Works for Quality Assurance of Long Steel Products

2) Current State and Problems of Adoption of Quality Assurance Equipment for Plate and Strip

The committee also held 6 meetings of 2 subcommittees.

\section{Transportation Committee}

The 7th meeting met to study "Intra-work Rail Transportation" and compiled a report on it.

15. Investigation Committee

The committee held the 9th meeting to study the investigation theme of 1982, " Problems on Steel Substitution Materials".

\section{Iron and Steel Analysis Committee}

The committee has 5 subcommittees and 3 working groups and their activities are described below. Working Group on Iron Ore Analysis completed its task by presenting to Agency of Industrial Science and Technology, Ministry of International Trade and Industry, a Draft JIS Revision on Iron Ore Analysis Method. 2 new working groups, namely, Working Group on Surface Analysis and Working Group on Fluorspar started respective activities in 1982.

(1) Committee

The 50th and 51st meetings were held. Celebrating the 50th meeting, the committee published "Analitical Control of Iron and Steel Making in Japan" in Japanese.

(2) Chemical Analysis Subcommittee

The 64th and 65th meetings examined Trace Elements Analysis of Highly Pure Iron and is planning to compile a report in 1983.

(3) Photoelectric Emission Spectroscopic Analysis Subcommittee

The 40th and 41st meetings were held to prepare and submit to the Agency of Industrial Science and Technology a Draft JIS Revision on JIS G 1253 Emission Spectroscopic Analysis by Photoelectric Measuring Method.

(4) Fluorescent X-ray Analysis Subcommittee

The 40th and 41st Meetings were held to make a joint experiment on Glass Bead Method of Iron Ore for mechanized acceptance analysis of imported iron ore.

(5) Non-metallic Inclusions Analysis Subcommittee

The 68th and 69th meetings were held to conduct a joint experiment on Extractive Separation Measurement for Sulphur Containing Compounds in Steel.

(6) Subcommittee on Analysis of Gas in Steel

The subcommittee held the 7 th and 8 th meetings to study analysis of nitrogen.

\section{Plant Engineering Committee}

The activities of 3 subcommittees of the committee are described in the following.

(1) Iron and Steelmaking Plant Engineering Subcommittee

The 26th and 27th meetings met to discuss:

1) Problems of and Measures for Size Changing and
Roll Segments Change in Continuous Casting

2) Reports on New Iron and Steelmaking Facilities

(2) Rolling Mill Engineering Subcommittee

At the 26th and 27th meetings, the following subjects were examined.

1) Problems of and Measures for Piping System

2) Controlled Rolling

(3) Electric Facilities Engineering Subcommittee

The 12th and 13th meetings were held on the following themes:

1) State of Troubles and Problems of Syristor Reonard System

2) Maintenance State and Measures for Problems of Syristor Reonard System

18. Committee for Utilization of Nuclear Energy

Following the dissolution of Engineering Research Association for Nuclear Steel Making in December, 1981, the committee reorganized itself to have 2 subcommittees, Technology Subcommittee and Patent Subcommittee, to continue its previous activities.

2. Basic Research Association on Specific Subjects

1. Committee on Basic Physical Properties of Coking Coal

Having completed the 5 year activities, the committee published a report and held a reporting meeting. Following themes were covered in the report.

1) Molecular Weight and Coking Power of Reduced Products by Coal

2) Characterization of Metallurgical Coal in Terms of Coking Characteristics

3) Basic Research on Distillation Reaction of Coal

4) Measurement of Thermal Properties in Coal Distillation Process

5) Basic Research on Reactivity of Coke

6) Basic Research on Fracture Mechanism of Coke

7) Study on Strength and Friability of Coke

2. Committee on Basic Research of Surface Properties of Steel

The committee started its research in March, 1982 and held 4 meetings. In order to concentrate its research activities on a few major issues, the committee received lectures from specialists in the related fields. Samples to be used in the joint research have been almost completed for a full-scale operation in 1983.

3. Committee on Basic Behavior of Coal Carbonization

This committee was established in 1982 and started researches on the following themes:

1) Gharacterization of Steam Coal

2) Basic Research on Coking Mechanism

3) Analysis of Coke Fracture Mechanism

\section{Joint Society on Iron and Steel Basic Research}

This Society is managed jointly by Japan Society for the Promotion of Science, the Japan Institute of Metals and ISIJ, whereas ISIJ acts as its secretariat.

The Society consists of several committees each of which carries out basic research on a specific subject in the field of iron and steel as joint works of specialists of public and academic research organizations and private firms. In principle, the committees are constituted to complete researches on specific subjects in 
the period of 5 years and publish reports on respective subjects. Some of the committees hold seminars and symposia open to the non-committee members to exchange views with researchers in the fields concerned.

1. Committee on Reaction within the Blast Furnace

The committee completed the 5 year research and published a report titled "Phenomena in Blast Furnace and its Analysis".

2. Gommittee on Non-metallic Inclusions Shape Control

The 9th, 10th and 11th meetings were held and "Interim Report" which compiles research achievements up to 1982 was published.

\section{Committee on Wear of Iron and Steel Products}

The committee held the 11 th to 14 th meetings to analyze "Questionnaire on Roll Wear" by receiving research reports of each member.

\section{Committee on Mechanics Related Behavior in Con- tinuous Casting}

The 6th, 7th and 8th meetings met to compile photo data on breakage of continuously cast semiproducts and discussed on 14 papers including one on Stress Analysis of Continuously Cast Semi-products.

5. Committee on Liquid Material Refining Reaction

The committee held the 7 th to 10 th meetings to discuss 22 papers on Equilibrium Constants on Dephosphorization of Hot Metal and Molten Steel, Reaction Mechanism and Measurement of Activities of $\mathrm{P}_{2} \mathrm{O}_{5}-\mathrm{Fe}-\mathrm{O}$ system. At 7 th meeting the committee prepared an interim assortment of published research literature.

\section{Committee on Strength of Iron and Steel in Various Environments}

This committee was established in 1982 and held 2 ordinary meetings to decide on the research plan following two preparatory meetings, which include a common test on strength of iron and steel in marine environment together with search for relevant literature.

\section{Other Technical Committees}

\section{Standardization Committee}

(1) The 15th International Conference of ISO/TG 17/SC 12 was held at Keidanren Kaikan, Tokyo, from October 18 to 20, 1982, with 8 countries represented (Australia, China, F. R. Germany, Japan, Sweden, Tanzania, U. K. and U.S.A.). The conference examined proposed standards for cold-rolled carbon steel strip with over $0.25 \% \mathrm{C}$, hot-dip Al-Zn coated steel sheet, hot-rolled steel sheets of higher yield strength with improved formability, and polyvinyl and other organic-coated steel sheet and a letter symbol for steel sheets.

(2) New data sheets on "Structural Steel Plates for Fracture Toughness Value" was published as Data Sheets Series, Part IV, covering 499 items of Vnotch Charpy Impact Test, 119 on Low Temperature Tensile Test, 123 on Deep Notch Test, 90 on COD Bend Test, 89 on Double Stretch or ESSO Test, and 108 on NRL Drop Weight Test.

(3) Draft JIS revision on 9 standards on carbon steel pipes for ordinary piping, arc welded carbon steel pipes and steel pipes for low temperature service and others were prepared as an entrusted project of Agency of Industrial Science and Technology. As an independent project, the committee prepared a new draft standard for $70 \mathrm{~kg} / \mathrm{mm}^{2}$ yield strength plates for welded structure as well as draft revision on standards for steel plates for pressure vessels for intermediate temperature service, spring steels, carbon steel plates for pressure vessels for low temperature service and hollow drill steels.

(4) Following the establishment of manufacturing method of standard specimens for adjustment and calibration of impact testing machine in 1981, the committee proceeded with preparations for the supply system to domestic users in cooperation with National Research Laboratory of Metrology and Nippon Kaiji Kyokai (NK) in 1982.

\section{High Temperature Strength Research Committee}

The committee has several subcommittees, each of which conducts specific activities outlined below:

1) High Temperature Creep and Fatigue Test Subcommittee

2) Data Sheet Preparation Subcommittee

3) National Research Institute for Metals (NRIM) Creep Data Sheet Subcommittee

4) Greep Strength Extrapolation Subcommittee

5) Notch Effect Test Subcommittee

6) High Temperature Embrittlement Subcommittee, which was set up to replace High Temperature Tensile Test Subcommittee in July, 1982.

\section{Test Blast Furnace Committee}

The committee held the 35 th meeting and a report meeting on the 29th operation of the pilot blast furnace at the University of Tokyo.

\section{Materials Engineering Committee}

The 45 th, 46 th and 47 th meetings met to receive 9 papers on controlled rolling and controlled cooling, impacts of diameter of crystal grains on fracture toughness value and others. As optional study, joint researches are being conducted on the theme of effect of high cleanness on fracture toughness value of steel materials.

5. Committe on History of Iron and Steel Science and Technology

Ironmaking Working Group and Education Working Group compiled reports, respectively.

6. International Iron and Steel Technical Gommittee

The committee met twice to receive reports on the 15th IISI TECHCO (Finland) and TECHGO Working Group.

7. Committee on Iron and Steel Standard Samples for Analysis

The committee held the lecture meetings in Tokyo and Osaka in February, 1982, for explaining how to use iron and steel standard samples. For the rearrangement of manufacturing and distribution system of standard samples aiming at an organized planning, Planning Group and Technical Group were newly established. At present, the committee is distributing new standard samples of high purity iron of $99.9 \%, 4$ kinds of special steels containing boron 
and Iscol hematite.

8. Japan Pressure Vessels Research Gouncil (JPVRG)

(1) Subcommittee on Hydrogen Embrittlement

Task Group I (TG-I) presented its final report of joint research at PVRG May Meeting while TG-III presented their report in the Fall Meeting. TG-II published a report in Japanese in September, 1982 and is preparing an English version to present at the Winter Meeting.

(2) Subcommittee on Pressure Vessel Steels

The committee met twice while the task group held 4 meetings. The search for reference literature on "Non-uniformity in toughness values of weldment of pressure vessel steels and the metallurgical analysis" was completed. The committee is preparing a report to be submitted at PVRG Winter Meeting. This report is to include the reference literature classification by causes, cause chart, and analysis of the data.

(3) Subcommittee on Non Destructive Examination of Materials for Pressure Components

5 committee meetings and 4 working group meetings were held and tests on Test Nozzles No. 3 and No. 9 for PISG II were conducted.

9. High Strength Line Pipe Research Gommittee (HLP)

The committee decided to make a joint research on hydrogen induced brittleness caused by sour gas (HIC Subcommittee) and carry out a burst test using commercial gas in U.K. on October 9, 1982.

\section{Japan Iron and Steel Technical Infor- mation Center (JISTIC)}

JISTIC's technical information services are carried out with supervision of Center Management Committee and its subordinate committees, namely, Editorial Committee, Information Retrieval Committee, Library Service Committee, and Joint Research Meetings.

Principal activities are outlined below:

(1) Input and Output Cooperation to Japan Information Center for Science and Technology (JICST)

JISTIC provides 4,500 inputs to JICST while terminals at JISTIC are used for output for $45 \mathrm{~min}$ per working day at average.

(2) Library Service

The Library owns 800 items of conference proceedings and 320 items of numerical data files for card retrieval beside usual periodicals.

(3) Publication of Current Iron and Steel Technology

The contents of this monthly publication, which are mainly abstracts and contents from various periodicals and other relevant articles, a sort of SDI, were revised from time to time and 1,000 copies are published.

(4) Documentation on Papers Presented at the Joint Research Society of ISIJ

Papers are microfilmed for distribution (available only to member firms in the Society) and their content bulletins are also available.

(5) Joint Study on Reference Retrieval Techniques Using On-line Terminal

The study report will be distributed as Information
Retrieval Sampling Test Bulletin.

(6) Projects Entrusted from Agency of Industrial Science and Technology

2 research projects were completed in 1981 .

JISTIC's activities have been attracting worldwide attention and the Center has been receiving a considerable number of visitors and inquiries from abroad.

\section{ISO Secretariat Activities}

\section{Secretariat of ISO/TC 17-Steel}

The 14th Plenary Meeting of ISO/TG 17-Steel took place in Tokyo from October 25 to 29, 1982 at Keidanren Kaikan Building.

It was the first TG 17 Plenary Meeting held in Japan and at the same time the first Plenary Meeting hosted by Japan after she has assumed the Secretariatship of this important TG.

Forty delegates from 16 (of which two by proxy) countries, including Tanzania for which it was a debut, attended the meeting. The proceedings went on for three and a half days to complete all 18 items with 78 working documents and 14 resolutions were formulated.

Under the Ghairmanship of Mr. A. Aoki (Japan) the delegates had heated discussions over many important items and the atmosphere throughout the meeting was the need for improvement in productivity of International Standards for steel and rationalization of procedures. Some procedual changes were proposed in this respect to comply with the present needs. In addition, taking into account the current world economic situation it was agreed to suspend some low priority items as they stand.

Besides the sessions, there was an Industrial Tour to NKK Ohgishima (Keihin Works) in which the robots for preparation of test pieces and carry-out of the mechanical testing drew attention of the delegates.

Furthermore, the delegates representing different countries deepened their friendship through receptions and other social events so the whole week was spent in an internationally cordial atmosphere.

\section{Secretariat of ISO/TC 17/SC 1-Methods of Deter- mination of Chemical Composition}

Since assuming the responsibilities in 1980, the Secretariat has circulated 200 official documents and handled various items. As a proof of these achievements, during this period, 4 ISO Recommendations were transformed into ISO Standards making the total of 8 ISO Standards in 20 years. In addition to the above, SC 1 voted on revision of ISO Standards and a Draft Proposal for one standard and sent them to the ISO Central Secretariat as Draft ISO Standards.

The 9th international meeting was held from May 24 to 28, 1982 at Keidanren Kaikan in Tokyo, to reactivate the activities of SG 1. 27 members from 9 countries under Dr. Kazuo Kawamura (Deputy Director of Fundamental Research Laboratories of Nippon Steel Corp.) as chairman examined 27 agenda 
items, 13 proposals on standards, 88 documents and the Secretariat proposal on procedures for activities of SC 1 to make effective and speedy business.

Agreements were reached on the following:

1) Adoption of Resolution on " Procedures for activities of SG 1 ",

2) Final approval on 4 Draft Proposals on standards

3) Establishment of working groups to carry out in- ternational cooperative experiments to incorporate analytical precision in standards and to develop analysis methods (Japan participated in all of the working groups and was designated as the convener of 4 working groups)

4) Adoption of Resolution on proposals for 2 new work items 